\title{
Virtual Leadership in the digital era for Church
}

\author{
Dr. Kusman Sudibjo, M.Th. \\ \{Royalb1007@gmail.com\} \\ Sekolah Tinggi Teologi Pelita Kebenaran Medan
}

\begin{abstract}
The current paper proposes an evaluation of the current implementation and projection of the future possibility of virtual leadership in church organizations. Two main theoretical viewpoints are used as a basis of the evaluation, namely Hanna (2007) and Hamilton and Scandura's (2003) views on e-mentoring. The data are observations on current Information Technology (IT) implementation in church; the sources of data are churches as observed by the researcher as an insider. For analysis, the method applied is forecasting based on contextual considerations, connecting the principles proposed by theoretical views to current implementation. The current dominant trend in IT application has not reached its fullest potential. The fullest potential can be made if church organization move towards the application of IT in the domain of governance in leadership. IT technology can be used to allow communication for mentoring with the present day application of teleconferencing media which has allowed a more intense use of IT to facilitate meetings.
\end{abstract}

Keywords: virtual leadership, church organization, IT, e-mentoring, trend

\section{Introduction}

In recent years, organizational performances can be seen to have received great benefits, thanks to the transformation of traditional methods of e-commerce into more innovative utilization of technology in the effort to achieve organizational goals. Innovation and creativity are in the growth of organization. Jeff Bezos, for example, surprised the world by appearing on top of individual income ranking by using technology to further facilitate commercial activities, allowing people across America and other parts of the world to get their thanksgiving meal by means of online shopping. The company he founded- Amazon-has proven the ability to embrace business relationships with anyone without discrimination and ensuring commercial processes without complications in operations.

IT presents a vast space for innovation and flexibility that cannot only represent traditional practices in doing activities but also transforming efforts into never-before thought of methods. Organizations can merely apply their wildest imagination, and software can be created to realize and facilitate that concept. With this in mind, Christian leadership or church leadership also taking the form of organizations must also give full consideration to adopting this approach to maximize results such as changing daily office practices, broking down both geographical and denominational barriers, enhancing productivity and procrastination. 
The current paper proposes a plausible model of implementation of e-leadership in church leadership based on available theoretical views on e-leadership. Thus, the research problem can be formulized in the question as follows; what model of e-leadership is plausible for church leadership?

\section{Theoretical Review}

\subsection{Virtual leadership}

Sofie Sandell mentioned in her book Digital Leadership ( 2013), many companies in the world have access to internet and advanced technology and everyone can explore creativity and the creative leadership style. Hambleya, O'Neil and Kline (2006) explored the up paradigm of activity that can now be executed anytime, anywhere, in real space or through digital media. Leadership within this platform is called Virtual Leadership or e-leadership. Virtual leadership in organizations can be defined as a social influence process mediated by advanced information technology to produce a change in attitudes, feelings, thinking, behavior, and/or performance with individuals, groups, and/or organizations (Avolio, Kahai, and Dodge 2000). Such form of leadership can take place at various levels within an organization. The process underlying e-leadership substantially comprised of interactions over electronic media between one-to-one as well as one-to-many.

\subsection{E-leadeship}

In order to evaluate how technology impacts leadership and vice versa, an approach called Adaptive Structuration Theory (AST) is incorporated, which is based on the assumption that there exist structures that guide human action. These structures can be rules and resources that are set schemas used in planning. Leadership is a part organization structures that technology helps to create. However, leadership and technology impact can transform organization structures. Therefore there is a recursive relationship between leadership and technology, affecting and being affected by the other as well as transforming and being transformed by the other. Hanna (2007) A study by World Bank (Hanna 2007) was conducted to find out how e-leadership is applied to the public and government sectors. The study was actually intended to facilitate institutions to be competitive in a real knowledge-based economy. Several trends were identified:

a) A shift toward direct engagement of top-level leaders as an e-leader in organizations;

b) There is a move towards institutionalized structures in response to the challenges of the technology-enabled development;

c) Countries are building Information and Communications Technology (ICT) agencies that reports directly to top leadership; d) Institutions start to integrate e-governance into their framework. According to Hanna a number of considerations are important aspects of eleadership, namely design of e-institutions, models of e-institutions, success factors, and institutional capabilities.

The concept of e-mentoring is an important factor in the success of the application of eleadership (Hamilton and Scandura 2003). E-mentoring offers benefits as well as presents challenges. Many have testified that mentoring does make a difference in the effort to improve all aspects of an organization, therefore e-mentoring provides new opportunities to facilitate relationship building programs. Among the challenges of e-mentoring are individual and interpersonal barriers and the nature of work that is constantly experiencing change. 
According to Hamilton and Scandura (2003) the dimensions of e-mentoring consists of functions and phases.Technology can play critical role on the implementation of e-mentoring as long as the technology has adaptability to situational and usability factors.. Nevertheless technology and mentoring are still in the development phase and cannot be viewed as an easy task. There are paradoxes resulting from the complexity with regards to impact of digital technology on leadership (Pulley and Sessa 2001).

Swift and mindful : The availability for fast processing, but the need for careful decision making.

individual and community : Top-down and grass-roots: top-down approaches allow uniformity of vision but the needs grass roots must be met and not compromised.

Details and big picture $\quad$ : A lot of attention must be put into the details, however eleadership must keep in mind the big picture

Flexible and steady $\quad$ : Programs must not be rigid and allow flexibility, however they must be relatively stable in terms of structure

It is crucial that elements of an organization identify together and participate in leadership at every level so as to overcome e-leadership implementation challenges, one of which is in creating a culture that accommodates input and feedback to leadership (Pulley and Sessa 2001). E-leadership is an emerging trend that is without ambiguity, however the difference between traditional leadership and technology-based leadership (Gurr 2004). Leaders in technology-based organizations are required to overcome associated behavioral complexities. An appropriate social climate must firstly be established by maintenance of effective communication. Leaders are still required to exemplify effective interpersonal skills using technology.

\subsection{Church and digital leadership}

Sudibjo (2018) in his book Theopreneurical Leadership concluded that the best future leader is a leader who has special ability to run the foresight and insight pattern of leadership principles continuously and consistently. Johansen (2012) who is the president of Institute For The Future in his book Leaders Make The Future introduced eight enduring leadership principles such as Get there early, Physical and Mental Exercise, Active Attention, Readiness Discipline, Urgent Patience, Story Telling and Listening, Humble Strength and Synchronicity. Study made by Brooks (2013) mentioned the practical reason why organization such as church organization need to go to digital era based on few data : Over 1 billion people own personal computer, 1,4 billion people use internet, 5 billion people have mobile phone which 1.08 billion are smartphones. Thousand of those users might live within distance of your church.

\section{Method}

The data in the current study are records of implementation e-leadership in the current state of church organization particularly in Indonesia. The sources of data are selected observations based on the available theoretical views of the topic. Consequently, the research method primarily utilizes observation as a method of data collecting. As for analysis, the method applied is forecasting based on contextual considerations, connecting the principles proposed by theoretical views to a future implementation. 


\section{Analysis}

\subsection{Application of e-leadership}

In light of Hanna's (2007) study on the application of leadership e-leadership in public and government sectors, from which several trends were observed. The following analysis can be made.

Table 1: Trends of IT application in Medan church organization based on observation

\begin{tabular}{|c|c|}
\hline Application of e-leadership & Evaluation (in Church organizations) \\
\hline $\begin{array}{l}\text { A shift toward direct } \\
\text { engagement of top-level leaders } \\
\text { as an e-leader in organizations }\end{array}$ & $\begin{array}{l}\text { Church leaders in Indonesia have been found to have } \\
\text { promoted the use of IT in particular areas of church activity. } \\
\text { These are are directed towards several aims: } \\
\text { 1) To advertise church presence and events: This has become } \\
\text { common practice for many years. Churches no longer use } \\
\text { newspapers as media for advertisements and have opted } \\
\text { towards promotion through social media. } \\
\text { 2) To achieve cost-effectiveness: printed bulletins containing } \\
\text { announcements, basic information, monthly thematic } \\
\text { messages, schedules, etc. have been partially replaced with } \\
\text { smartphone applications, thus cutting costs for printing. } \\
\text { 3) To improve administration: databases which are in the } \\
\text { form of manual records are in the progress of being } \\
\text { transformed to online databases for better integrity of data } \\
\text { and ease of access and analysis }\end{array}$ \\
\hline $\begin{array}{l}\text { There is a move towards } \\
\text { institutionalized structures in } \\
\text { response to the challenges of the } \\
\text { technology-enabled development }\end{array}$ & $\begin{array}{l}\text { Divisions in organizational structure are being created to } \\
\text { accommodate the duties dealing with computer technology } \\
\text { and the entailed responsibilities. }\end{array}$ \\
\hline $\begin{array}{l}\text { ICT agencies that reports } \\
\text { directly to top leadership }\end{array}$ & $\begin{array}{l}\text { As of the present time, divisions in charge of ICT reports to } \\
\text { leadership, but not for comprehensive implementation and } \\
\text { not on a highly regular basis. }\end{array}$ \\
\hline $\begin{array}{l}\text { Institutions start to integrate e- } \\
\text { governance into their framework }\end{array}$ & $\begin{array}{l}\text { Up to the present point, the utilization of IT has not } \\
\text { implemented on the level governance in church organization. }\end{array}$ \\
\hline
\end{tabular}

Based in the above observations, it can be seen that the current dominant trend in IT application has not reached its fullest potential. The fullest potential can be made if church organization move towards the application of IT in the domain of governance in church leadership. Governance in this case deals the principles and procedures in distributing authority and responsibility, involving selection of human resource and their endowment.

\section{2 e-mentoring}

As posited by Hamilton and Scandura (2003), e-mentoring is an important factor in the success of the application of e-leadership. It is envisioned that e-mentoring offers benefits as well as presents challenges. On the basis of this a matrix can be proposed to analyze the three main areas of e-mentoring and each particular benefit and challenge evaluation as in the following table. 
Table 2: Matrix of three main areas of e-mentoring and evaluation of benefit and challenge

\begin{tabular}{|c|c|c|}
\hline Aspects & Benefits & Challenges \\
\hline $\begin{array}{l}\text { Facilitation } \\
\text { of } \\
\text { relationship- } \\
\text { building } \\
\text { programs }\end{array}$ & $\begin{array}{l}\text { Just as social media is created to provide } \\
\text { a means for interpersonal } \\
\text { communication, in the same manner IT } \\
\text { technology can be used to allow } \\
\text { communication for the use mentoring in } \\
\text { church organizations. The maximization } \\
\text { of mentoring in organizations can be } \\
\text { considered as an effort of knowledge and } \\
\text { skill transfer. The main advantage is that } \\
\text { it allows faster orientation for the person } \\
\text { in the new role. }\end{array}$ & $\begin{array}{l}\text { Traditionally it is perceived that } \\
\text { mentoring requires a form of meeting } \\
\text { and that without direct encounter the } \\
\text { process would be able to take place } \\
\text { effectively. } \\
\text { However, the present day application } \\
\text { of teleconferencing media has } \\
\text { allowed more frequent and intense } \\
\text { use of IT to facilitate meetings and } \\
\text { people have realized that with } \\
\text { familiarity, they can be as } \\
\text { comfortable as direct encounter } \\
\text { meetings. }\end{array}$ \\
\hline $\begin{array}{l}\text { Functions } \\
\text { and Phases }\end{array}$ & $\begin{array}{l}\text { Mentoring may have several functions, } \\
\text { such as orientation to the new } \\
\text { environment and sharing information on } \\
\text { how to face and overcome complex } \\
\text { matters. } \\
\text { Therefore, mentoring also goes through } \\
\text { phases. Mentoring usually requires } \\
\text { effective communication between two } \\
\text { individuals. }\end{array}$ & $\begin{array}{l}\text { The main challenges that can be } \\
\text { expected are in the fact that } \\
\text { mentoring is not a human-machine } \\
\text { encounter but a human-to-human one. } \\
\text { Therefore, if faced with complicated } \\
\text { schedules, meeting opportunities } \\
\text { might be hard to find. }\end{array}$ \\
\hline $\begin{array}{l}\text { Adaptability } \\
\text { to } \\
\text { situational } \\
\text { and } \\
\text { usability } \\
\text { factors }\end{array}$ & $\begin{array}{l}\text { Programs can be designed to be flexible } \\
\text { enough to allow adaptability and } \\
\text { usability. With today's technology, there } \\
\text { is virtually no limit to what can be } \\
\text { demanded on the e-mentoring software } \\
\text { designers. }\end{array}$ & $\begin{array}{l}\text { Without clear and detailed requests of } \\
\text { specifications, e-mentoring software } \\
\text { designers will understand what are } \\
\text { the limitations that they need to avoid } \\
\text { and so much preparation is needed to } \\
\text { understand the product that will fully } \\
\text { be helpful to be used by the mentors } \\
\text { and mentees. }\end{array}$ \\
\hline
\end{tabular}

\section{Conclusion}

Church leaders in Indonesia have been found to have promoted the use of IT in particular areas of church activity for several purposes: 1) to advertise church presence and events: This has become common practice for many years, 2) to achieve cost-effectiveness: printed bulletins containing announcements, basic information, monthly thematic messages, schedules, etc. have been partially replaced with smartphone applications, thus cutting costs for printing, 3) to improve administration: databases which are in the form of manual records are in the progress of being transformed to online databases for better integrity of data and ease of access and analysis. Divisions in organizational structure are being created to accommodate the duties dealing with computer technology and the entailed responsibilities. As of the present time, divisions in charge of ICT reports to leadership, but not for comprehensive implementation and not on a highly regular basis. Also, the utilization of IT has not implemented on the level governance in church organization. The current dominant trend in IT application has not reached its fullest potential. The fullest potential can be made 
us if church organization move towards the application of IT in the domain of governance in church leadership. Governance in this case deals the principles and procedures in distributing authority and responsibility, involving selection of human resource and their endowment.

IT can be used to allow communication for the use mentoring in church organizations. The maximization of mentoring in organizations can be considered as an effort of knowledge and skill transfer. The main advantage is that it allows faster orientation for the person in the new role. The present day application of teleconferencing media has allowed more frequent and intense use of IT to facilitate meetings and people have realized that with familiarity, they can be as comfortable as direct encounter meetings.

Mentoring usually requires effective communication between two individuals and thus the main challenges that can be expected are in the fact that mentoring is not a human-machine encounter but a human-to-human one. Therefore, if faced with complicated schedules, meeting opportunities might be hard to find. Moreover, programs can be designed to be flexible enough to allow adaptability and usability. With today's technology, there is virtually no limit to what can be demanded on the e-mentoring software designers. Without clear and detailed requests of specifications, e-mentoring software designers will understand what are the limitations that they need to avoid and so much preparation is needed to understand the product that will fully be helpful to be used by the mentors and mentees.

\section{References}

[1] Avolio, B. J., Kahai, S., \& Dodge, G. E. (2000). E-leadership: Implications for theory, research, and practice. The Leadership Quarterly, 11(4).

[2] Brooks Mark (2013)., The Digital Church :How to use The New Tools of The Technological And Communication Revolution In Your Church, The Charis Group USA.

[3] Johansen Bob., Leaders Make The Future:Ten New Leadership Skills For Uncertain

[4] World, Berrer-Koehler Publishers,second edition,San Francisco, 2012

[5] Gurr, D. (2004). ICT, leadership in education and e-leadership. Discourse, 25(1), 113-124.

[6] Hamilton, B. A., \& Scandura, T. A. (2003). E-mentoring: Implications for organizational learning and development in a wired world. Organizational Dynamics, 31(4), 388402

[7] Hambleya,ONeil and Kline (2006), E-Leadership ,Emerging Leadership Journeys, Vol 4 Iss I

[8] Page 1-36, 2011 Regent University School of Global Leadership\&Entrepreneurship

[9] Hanna, N. K. (2007). e-Leadership institutions for the knowledge economy. Washington, D.C.: The World Bank.

[10] Pulley, M. L., \& Sessa, V. I. ('2001). E-leadership: Tackling complex challenges. Industrial and Commercial Training, 33(6/7).

[11] Sandell, Sofie (2013). Digital Leadership :How creativity in Business can propel your

[12] brand \& boost your results, Allen House Publishing Company Limited, 57

[13] Sudibjo Kusman (2018)., Theopreneurical Leadership, Pelita Kebenaran

[14] Press,Medan,Indonesia 